\title{
Is the Elephant Still in the Room: The Governance of Private Jordanian Universities (PJUs)?
}

\author{
Osama Mansour ${ }^{1}$, Ahnaf Al Smady ${ }^{1}$, Ahmad Lutfi $^{1} \&$ Mustafa Abdelkareem ${ }^{2}$ \\ ${ }^{1}$ Faculty of Economics \& Administrative Sciences, Accounting Department, Applied Science Private University, \\ Jordan \\ ${ }^{2}$ Faculty of Economics \& Administrative Sciences, Accounting Department, Qatar University, Doha, Qatar \\ Correspondence: Ahnaf Al Smady, Faculty of Economics \& Administrative Sciences, Accounting Department, \\ Applied Science Private University, Jordan. Tel: 962-772-294-790. E-mail: a_alsmady@asu.edu.jo
}

Received: March 28, 2015

Accepted: May 12, 2015

Online Published: May 25, 2015

doi:10.5539/ibr.v8n6p153

URL: http://dx.doi.org/10.5539/ibr.v8n6p153

\begin{abstract}
This research aims to provide a better understanding of the governing bodies and methods in private Jordanian universities (PJUs). This is a descriptive research uses secondary and primary research tools such as interviews, archival documents, observations, and reports. These tools were all employed in this study to accomplish the objective. Nineteen interviews with financial managers, auditors, and Ministry of Higher Education (MoHE) staff were conducted. This research emphasizes that higher education in Jordan is considered one of the best systems in the Middle East and North Africa countries. The findings show that there is much competition in the private higher education and this motivates to research the governance methods. There is a trend in the world towards private higher education. Unlike their counterparts in the world, PJUs do not receive any support from the government, but also pay over than $25 \%$ of their income to the government and they are for the most part financed by student tuition fees. MoHE by law and through different procedures intervenes in the PJUs management and decisions.
\end{abstract}

Keywords: Private Jordanian University, governance, education

\section{Introduction}

Previous higher education literature asserts that while there is rising enrollment, universities are experiencing declining budgets and heightened competition in attracting students (El-Sheikh et al., 2012). Such a situation causes financial problems and enhances the demands for accountability (Mah'd, 2010). This requires universities' directors not only to improve their performance, but financial problems cause management to properly make decisions. Prior studies state that such difficulties force governments to change the funding strategies in Higher Education (HE). Governments encourage universities to move towards market solutions, such as privatisation and deregulation (Mansour, 2014; Al-Lamki, 2002).

Since 1990, privatisation or adopting market orientation has been the government solution for the HE financial problems. This reform addressed the shrinking of government funding by encouraging this movement. Meanwhile, HE institutions expected to be more accountable for how its diminishing portion of public financial support is spent. In Jordan, private HE institutions do not receive any financial support from the government, but also they pay for the government accreditation fees and different kind of taxes. Privatization plays a vital role when the government refuses to provide the essential support for an expanding HE sector. Prior research shows that universities' enrolment grows very quick in almost all over the world. This is notable in the developing countries, such as East Asian countries, the Middle East, Latin America, the former Soviet Republics, or even in the USA and Europe (Altbach \& Knight, 2007, Mah'd, 2010; Mansour, 2014).

In the last three decades Jordanian higher education has developed steadily in regards to content, programmes, and methods of teaching and learning that affect both the quality and quantity of education (Mah'd, 2010; El-Sheikh et al., 2012). Moreover, Mah'd (2010) explains that exceptional universities' system exists in Jordan. This system offers choices and alternatives not always available in developing countries (see World Bank, 1996). These options are different in the ownership style (public and private), patterns of educational system (universities and colleges) and are based on credit-hour system (El-Sheikh et al., 2012). These options allow 
students to select courses according to their study plans.

Private universities in developing countries struggle to manage their limited resources (Mah'd, 2010). In Jordan, a decision to adopt a new approach for the financing and management of HE has been taken since both funding and ownership belong to private sources. Moreover, Ministry of Higher Education (MoHE) plays a role in the Jordanian context. MoHE requires all universities to develop budgeting system to significantly increase their control over the private HE sector, thus establishing some norms and standards to develop these universities to follow the government's direction and to facilitate the monitoring and evaluation of these institutions' performance. Simultaneously, there are no government subsidies or tax exemptions (like those given to public universities) available to private universities.

In Jordan, the MoHE is in charge of developing in higher education in terms of quality and excellence. The MoHE implements accreditation policy to oversee private universities and to maintain quality and excellence. However, the MoHE law maintains for each university in Jordan its autonomy, the MoHE is concerned about the quality of education in these universities. One of the methods that MoHE uses to protect quality is the budget process as it tries to keep commercial companies away from the educational process, and gathering budget information to match and compare for the purpose of research and development. Prior research finds that more than two thirds of private universities think that the MoHE is trying to oversee private universities and to centralise strategic decisions into the hands of the MoHE through the budget (Mah'd, 2010). On the other hand, private universities are not well represented in the MoHE council; while private universities are more than public universities, every public university is represented in the MoHE council by its president, while all private universities are represented by just one person (Farhan, 2000). Moreover, Mah'd (2010) asserts that the accreditation system is applied to private universities but not to public ones. According to Farhan (2000), there is discrimination in dealing with universities and this has a negative impact on the educational process. This means that inequality exists in the MoHE's treatment of private and public universities. While, there is an evidence to suggest that some private universities perform much better that some public universities do in terms of educational services, development, and student quality (Burke \& Al-Waked, 1997; Mah'd, 2010).

It is argued that that the likelihood of PJUs being perceived as effective increases when they manage to align the expectations of stakeholder groups with respect to good governance. Thus, including stakeholder's perceptions in measuring effectiveness will improve understanding of PJUs governance and therefore the quality of governance practices. Therefore, this research sheds light on the relations between the MoHE and PJUs. Moreover, the study will fill the gap throughout describing the PJUs governance and concentrating on the methods that the MoHE uses to oversee the PJUs as a case of governance understanding.

\section{Institutional Theory}

The institutional theory can explain the governance process in JPUs. Institutional theory assumes that organizations adopt structures and practices in response to actual or anticipated external changes or pressure. It can explain external pressures as: Coercive: example could be legislators and regulators. Normative: example could be professional institutes and agencies. Mimetic: example could be other governments. (DiMaggio \& Powell, 1998).These forces can improve the homogeneity of accounting practices across organizations and contribute to institutional isomorphism (Baker \& Rennie, 2006). It can be argued that institutional theory as one of the most appropriate theory for explaining JPUs governance process. It can explain external pressures as:

Coercive: example could be legislators and regulators.

Normative: example could be professional institutes and agencies.

Mimetic: example could be other governments (DiMaggio \& Powell, 1983).

These forces can improve the homogeneity of accounting practices across organizations and contribute to institutional isomorphism (Baker \& Rennie, 2006). Pollitt and Bouckaert (2004) considered institutional theory as one of the most appropriate theory for explaining public-sector management reforms. Also it has been used in this current to explain how MOE were very influential in budgetary accounting form adoptions by JPUs. This has been done by using secondary and primary research tools such as interviews, archival documents, observations, and reports. These tools were all employed in this study to accomplish the objective. Nineteen interviews with financial managers, auditors, budget accountants and Ministry of Higher Education (MoHE) staff were conducted. MoHE by law and through different procedures intervenes in the PJUs management and decisions.

\section{Sample and Data Collection}

In this research a descriptive research using both primary and secondary research tools were employed. Nineteen 
interviews with financial managers, auditors in PJUs as well as ministry of higher education staff were conducted. Those interviewees were chosen as they are involved with the governing issues of the educational institutions. According to Saunders et al. (2012) interview is the one of the best methods that is used to seek new insights and to understand new phenomena. In this research, the interview was used to explore the governance issues and to understand the situation in JPUs.

\section{Background of Higher Education in Jordan and PJUs}

\subsection{Higher Education in Jordan}

In the last 25 years, privatization was one of the issues that Jordan has been interested in on a national scale, since it has been argued that this will improve competence, satisfy parents' preferences, make universities more accountable, and reduce government expenditure in higher education institutions (Kharman, 2005; Mah'd, 2010). This conception has been developed in order to enhance higher education development insofar as there is pressure to expand student numbers or to reduce costs, enhance research, and apply the result of such research more effectively. The attitude towards privatization is increasing and has changed dramatically (El-Sheikh et al., 2012).

In 1982, Jordanian Council of Higher Education was established to meet the need for regulation, planning and controlling HE policies. This council oversees the programs offered by both private and public higher education institutions through the Accreditation Commission, and the Higher Committee for Scientific Research. After three years, the MoHE and Scientific Research was established to collect relevant statistics, to approve the establishment of new institutions, to establish policies and practices and to apply the mission of the government's educational strategies (MoHE, 2008). The MoHE evaluates public and private institutions in terms of their programs' effectiveness in implementing higher education's vision, tasks, and objectives (El-Sheikh et al., 2012).

\subsection{The Governance of PJUs}

Private universities pay different kinds of fees and taxes to the MoHE, including a fixed amount for every student (general accreditation) and every major (special accreditation), as well as other fees. For example, in 2012 one private university paid about US $\$ 600,000$ in accreditation to the MoHE and over US $\$ 2,800,000$ in taxes to the government. Together, these taxes comprise around $20 \%$ of the university's total expenses. This trend applies to all private universities. However, private universities struggle to pay these fees to the government, as student tuition fees are their only source of funding. This is one of the reasons why there is a tendency amongst these private universities to be more accountable and effective than public universities in terms of resource use.

Law No. 19 of 1989 has defined private universities as every university, HEI, or a college where the course of study is no less than 4 years, or its equivalent, provides awards at least the bachelor degree. It is to be established, owned, managed, and supervised by a non-government body (Younis, 2002). Private universities are commercial companies; indeed, most of them are owned by families (whether or not these institutions are listed on the Amman Stock Exchange).

According to Law No. 43 of 2001 and Law No. 20 of 2009, each private university must have an autonomous budget that operates under the control of the president and is submitted through the trustees' board to the MoHE council. Prior research finds that, whilst employing the budget is compulsory in the private universities, the level of participation in the budget varies. The concerns over what factors may influence budget performance in PJUs are researched in this study.

The law allows investors to apply to the MoHE to establish a university. According to the law, financial and managerial autonomy are guaranteed. This enables university to own property and operates legally in the community. Five private universities are publicly listed on the Amman Stock Exchange. According to the law PJUs are all recognized as commercial companies and the board of directors represents the owners of the university. This requires all PJUs to meet the needs of the owners and in the same time satisfy the requirements of accreditation of the private universities law (El-Sheikh et al., 2012).

Board of directors, who represents the commercial company, is in charge of funding the university's buildings and properties. The university president who holds the responsibility for all university activities must not be one of the university owners. The HE council appoints the university president for four years and the president must be Jordanian professor. The board of directors is the business engine in the private universities. This board controls all financial and management issues, and sometimes academic issues. In other words, the general manager takes the important decisions and university management is under his control.

Every university must create a board called the university board headed by the president. This board consists of 
the vice president, deans, an academic from each faculty, two administrative managers, two persons from the local community, one current student, and one previous student (Mah'd, 2010). More operational, every university has a dean's board that discusses all academic issues, establishing new programs, appointing professors, assessing academics' work and nominating academics for scholarships. Each PJU must have a board of trustees appointed by the MoHE for four years and holds the power and authority to prepare the strategic plans and policies for the university (El-Sheikh et al., 2012). The board approves presidential decisions for organizing university activities, and on a term by term basis the board decides the students' numbers in each faculty and department.

\subsection{The Role of Ministry of Higher Education in PJUs}

The higher education council is the most authoritative and influential governance body in Jordanian higher education. In 2001, HE Act No. 43 was authorized (and annulled the previous Act). The allocation of government fund between public universities, the enrolments to both public and private universities and the annual entry standards lie in the hand of this council. Moreover, the accreditation of private universities and their programs (both initially and annually) and the senior appointments in public universities, as well as the presidents of private universities, are decided by the Higher Education Council. According to this law, all HE issues are controlled and supervised by the MoHE, with the following functions (Al-Tarawneh \& Mubaslat, 2011).

1) Implementing the overall policy and plans of higher education in the kingdom.

2) Creating an environment of coordination between universities private centers for consultations and research.

3) Signing agreements in the fields of higher education and scientific research.

4) Representing Jordan at international conferences.

5) Approving HEIs and their certificates.

6) Setting student eligibility rules for scholarships inside and outside of Jordan.

7) Following up the affairs of Jordanian students abroad through Jordanian cultural counselors.

In addition to functions given to MoHE, this Act provides the following major duties to Accreditation Council within the Ministry:

Defining regulations for the accreditation of HEIs, and amending and developing these in light of the general policy of HE.

Supervising the performance of HEIs and their commitment to applying the rules of accreditation.

Appointing the specialized committees needed to carry out the tasks of the Accreditation Council.

Ensuring that institutions of $\mathrm{HE}$ reach their pre-defined goals through continuous evaluation of their programmes.

Proposing schemes for regulations and rules of the Council's duties.

Publishing the Council's decisions concerning accreditation in the official media.

\subsection{Decision Making Structure in PJUs}

Previous literature assures that decision making in private universities has been affected by the MoHE (El-Sheikh et al., 2012; Mah'd, 2010). In Jordan, there is a prevalent conception that state universities generally provide better education than private universities do. The MoHE thinks that private university managers (represented by the board of directors) pay more attention to profit than to the quality of educational services. For this reason, the MoHE gives academics (the president and the trustees of private universities) more authority and power to make proper educational decisions.

While in public universities there is no board of directors, the Public and Private Universities Law of 2009 documents how every public university must have a board of trustees consisting of 13 members who hold at least a bachelor's degree. The members of the board of trustees are appointed by a royal decree for four years, and they are the university general policy makers, responsible for approving the budget and appointing the president of the university.

The structure of decision-making in these universities differs from that of other enterprises. While in universities the flow chart of authority is complex, normal businesses tend to operate on a simple, hierarchical decision-making structure (Covaleski \& Dirsmith, 1988). There are two main decision-making bodies in PJUs: the board of trustees and the board of directors. Formally, the board of trustees is responsible for all financial, 
management, for academic issues within the university, and for appointing the university president. This board is the policy maker when negotiating the budget and discussing expenditures. Whilst owners tend to minimise university expenses and the budget (Issa, 2000), trustees should guarantee that this tendency will not affect the quality of education.

The board of directors is primarily comprised of stakeholders and those who own the highest percentages of the university; it is in charge of the funding of building and estates as well as of representing the business side of the university. Issa (2000) states that sole business of the company that owns a Jordanian private university is the formation of the board of directors. According previous research, the board of directors controls all financial and management issues related to the university (El-Sheikh et al., 2012; Mah'd, 2010). Although the level of authority and decision-making power varies between universities, all private universities are controlled primarily by the owners through the board of directors. Therefore, budget decisions are made and approved by the owners and the MoHE policy is based on this. In order to protect quality of education, all private universities must be managed and controlled by academics through the trustees and the president. The MoHE apparently aims to separate the educational process in private universities from the commercial patterns (the university owners). This has been one of the main concerns highlighted by MoHE policies. An example of that, the MoHE does not recognize or accept any letter is not signed by the university president. Moreover, the Private Universities Law states that university management must be independent of university owners. For example, in the MoHE budget format, all expenses related to buildings, land, or construction should be separated from the overall university expenses and financed by the parent company (the owner). In reality, private universities are all managed by the owners through the council of directors, in which management and strategic issues are decided most of the time. In fact, the head of the board of directors, who is typically the general manager, has power over all university actions. Universities' documents and informal hierarchical authority structures demonstrate that strategic plans and decisions are normally made by the general manager. The internal system in each university forwards all payment and purchasing orders to the general manager, who approves the budget and other strategic decisions. According to Mah'd \& Buckland (2009) the internal system of the private universities states that the president and the board of trustees should sign the budget proposal after its being approved by the board of directors. The president and other academic managers manage educational issues, such as appointing academics, managing academic plans, and representing the university.

The management of private universities should not only think about funding and revenue sources, but they should also give more attention to finding ways of reducing educational costs whilst maintaining the quality of education (Mah'd, 2010). Until 2013, the MoHE restricts student numbers and does not allow any private university to accept more than 8,000 students. According to Mah'd and Buckland (2009) the MoHE thinks that quality of education can be affected by increasing the number of students in private universities. Recently, the MoHE responds to the universities pressure and starts allowing private universities to accept of more than 8000 students.

\subsection{Budgets in PJUs}

Several researchers have clarified the importance of the budget and resource allocation (see Moll, 2003; Covaleski et al., 2003; Horngren et al., 2009; and Drury, 2008). There is agreement among the respondents that the budget is one of the control tools which assists in decision-making, provides accurate information, and facilitates the matching of departments' revenue and expenditure. Budgets as planning systems provide better resource allocation to various departments and centres (see Magner et al., 1996; Drury, 2008). Magner et al. (1996) explain that organisations should engage in systematic operational planning for the near future and should consider how to best allocate limited resources among their various operating units. Private University Law Number 43 in 2001, and its amendments by temporary Law Number 63 in 2003, determines the private university budget and its sources. This is a summary of the main points in this regard:

1) There is an independent budget for the university.

2) The MoHE council approves of the university budget.

3) The University's budget income consists of:

a. Tuition fees

b. The revenue of real estate

c. Grants and donations

d. Investment activities 
4) The spending order must be decided by the president.

5) The university should set aside 3\% of the operational expenditures for scientific research, publications, training, and conferences, as well as $2 \%$ for sponsoring students for doctorate degrees.

6) The university must open an account (independent of the parent company owners) in a Jordanian bank.

7) The university must possess financial accounts and entries, and these accounts must be audited by a certified accountant appointed by the company.

8) The university must establish an internal audit unit which should present reports to the president.

9) The parent company is directly responsible for capital projects (buildings and maintenance) and should accommodate this fund as approved by the trustees' board in the budget.

10) The parent company is not allowed to intervene in any university managerial affairs or equipment, and the company deals with university activities which are not related to academic issues from outside of the campus.

The university budget is an annual plan approved by the MoHE council; it includes operational plans for the university and encompasses the activities, programmes, and services that are forecasted for a specific period. The university budget consists of two main parts: revenue and expenditure. Revenue is a financial estimation assessed by the financial department mainly on tuition fees. Expenditure is a financial reflection of the university plan for the next year, including all university expenses. The university budget covers the financial period starting from January 1st and ending on December 31st every year.

The budget is classified into three levels. The first level is referred to as chapters: every chapter includes sections, and every section consists of a number of items. The budget form is considered as a proposal for the university and the department's budget. If any other expenditure or revenue is not included in the form, the university can add it to the appropriate chapter and section. The law determines revenue and expense in the following areas:

\subsection{Revenue and Their Resource}

\subsubsection{Tuition Fees}

Tuition fees consist of two main types: tuition fees for normal programmes and tuition fees for private programmes (evening programmes). Every section consists of four main sources: tuition hour fees, services fees, administration fees, documents, and graduation fees.

Endowments and investment revenue

This consists of six sections:

Credit interest revenue;

Student revenue and staff delivery;

Cafeterias revenue;

Bookshops revenue;

Stocks and shares;

Other revenue.

- Consultations, research, and production activities;

- Grants, donations, and contracts;

- Payable revenue (this includes students' payable debts and other payable debts);

- Loans for building and maintenance (this is under the responsibility of the company and does not appear in the budget, but rather appears as a note for disclosure).

\subsubsection{Expenditures}

These should all be related to university activities, and are classified as follows:

1) Operational expenditures (salaries, wages, pensions and their attachments), including four main sections: salaries and wages, summer wages and extra time wages, recompenses and benefits, and the compensation of the board of directors.

2) Other operational expenditures (seven sections are included in this chapter): student activities and services, maintenance and necessities, shared expenses, contributions, accreditation, professional works and 
consultations, taxes, and other fees.

3) Scientific research and sponsorships (this chapter includes two main sections): scientific research, publication, training, and conferences, as well as sponsoring students for doctorate degrees.

4) Capital expenditure (five sections are included in this chapter): equipment and scientific devices, furniture and office equipment, vehicles, computers and programmes, and books and journals.

5) Payable expenditures: income taxes for the previous year.

6) Building and maintenance expenditures financed by companies' loans: this is not included in the budget and appears as a note.

The MoHE distributes a budget form to private universities. This form should be distributed to all faculties and administrative departments within the university. The faculties have different forms from those in administrative departments. Some specific departments have specific forms, such as the library form, to cope with the nature of these activities in that department. The budget format includes estimates for the current year, revisions for the current year, and estimates for the next year. The budget has been prrepared by the MoHE, and it is typically prepared by each university's budget committee and financial department. The MoHE distributes the budget forms to all private universities and requires these universities to follow the forms. While adhering to these forms is compulsory, universities can add, remove, or change items according to their activities. Mah'd (2010) shows that some PJUs rely on the budget committee and provide data to the committee through the financial department; others depend totally on the financial manager, thus demonstrating a central decision-making structure. Mah'd (2010) finds also that audit managers have a substantial influence on budget decisions and sometimes maintain the position of budget committee head.

In 2003, the MoHE generated a committee to re-establish the budget format in a manner designed to suit activities in all private universities. Basically, this format is developed from the experience of public universities, and it contains two main streams (revenue and expense). In most cases, after the revision of the budget by the budget committee and the negotiation of any unrealistic or vague items, budgets will be finalised and summarised in the final revision. The approval stage will take place after the budget has been finalised, and the budget, must be sent to the president, then to the deans' council, to the board of trustees, and finally to the MoHE council for approval. The MoHE council then revises the budget to ensure that the university is adhering to the law. Mah'd and Buckland (2009) finds that the aim of sending the budget to the MoHE is determining scientific research expenses, the responsibility of the parent company concerning the university activities, and facilitating the comparison between universities based on the budget data. The budget format encloses a separate budget form for each administrative department and faculty in the university. All administrative departments have the same budget format, which includes the same expense items, with the exception of a few departments that have unique features, such as the library and registry. While the budget form includes all expected expenses for the coming year, some managers or deans may require additional, unlisted expenses. Thus, they can add their required items to or remove any unwanted items from the budget at the time of preparation.

The Ministry revises this format; compares the actual and the budgeted accounts for the previous year. The difference between actual and budget should be the same as the approved transfers or additions. Another thing is that the Ministry is interested in checking university commitment when examining the science research account, as well as in monitoring the intervention of the parent company in the university's accounts. The MoHE emphasises the fact that they generated a budget committee to create a budget format for all private universities.

\subsection{MoHE Intervention}

The impact of external pressures on university management and governance is addressed in a considerable amount of literature (see Johnstone, 1998; Modell, 2006; Buckland, 2009; Mah'd \& Buckland, 2009). Governments in most of the world have a responsibility to oversee the provision of HE (this is to protect HE quality, or for reasons of market failure) (Johnstone, 1998). Thus, government intervention in university management and governance may have a major impact on a university's strategy. Moll (2003) states that Australian universities still resist external pressures, particularly pressure from the federal government, in favour of a managerial approach. She clarifies that Australian universities have restructured their governing bodies to accommodate government policies and changing community pressures to make decisions effectively, as well as to display a higher level of managerial competency. Covaleski and Dirsmith (1988) describe how the University of Wisconsin rejects the state budgeting format when this format does not support the university's goals and interests. We are addressing here that the government through different tools such as budgets are controlling the universities. However worldwide this may be valid for some cases in public universities, in Jordan private are 
controlled by the government. Private universities in Jordan do not receive any fund from government and they are required to follow the government direction while public are not required to do so.

\section{The Results}

In Jordan, although the MoHE and the Universities Law claim that all universities are independent institutions, the MoHE is in charge of supervising private and public universities in terms of their programmes, educational performance, admission policies, and approval of development and budgeting plans. Mah'd (2010) approved this by both the MoHE staff and universities' managements. The budget procedures, which have been established in the MoHE and which all private universities are supposed to follow, are an example of MoHE intervention.

The MoHE claims that, while each university in Jordan maintains its autonomy, the MoHE is concerned about the quality of education in these universities. The MoHE thinks that the budget process is one way of protecting educational quality by maintaining an appropriate percentage of scientific research, keeping commercial companies away from the educational process, and gathering budget information to match and compare for the purpose of research and development. Mah'd (2010) demonstrates that more than two thirds of private universities think that the MoHE is trying to oversee private universities and to centralise strategic decisions into the hands of the MoHE through the budget. Farhan (2000) finds that private universities are not well represented in the MoHE council; while private universities are more than public universities, every public university is represented in the MoHE council by its president, while all private universities are represented by just one person. The accreditation system is applied to private universities but not to public ones. According to Burke and Al-Waked (1997), there is a conceptual bias that private universities provide lower educational quality than public universities do. The MoHE asks all private universities to implement different criteria regarding quality of education, financing, management, and other issues, while this is not a requirement for public universities (Mah'd, 2010). According to Farhan (2000), there is discrimination in dealing with universities and this has a negative impact on the educational process. This means that inequality exists in the MoHE's treatment of private and public universities. There is evidence to suggest that some private universities perform much better that some public universities do in terms of educational services, development, and student quality (Burke \& Al-Waked, 1997; Mah'd, 2010).

In a public university, the dean is responsible for his own budget; he has a specific amount for the whole faculty budget, and he can distribute this amount according to the various needs and requirements of faculty activities. Conversely, in private universities there is a specific amount for every budgeted item and neither the dean nor the department head are able to order in excess of their item allowance. In general, both public and private universities allow the dean to establish his own budget, and they negotiate it with him. In public universities, the dean can control and organize his activities within his overall allowance; however, in private universities there is an items' budget controlled by the financial management, and the dean is able to make decisions only according to the items' allowances. This helps to control the expenses, enhances the responsibility attribution, and facilitates decision-making.

\subsection{The Perceptions of the Budget Preparers and MoHE Staff}

This research demonstrates the views of the universities' financial managers, audit managers, and budget accountants and MoHE staff. First, this research explores the views regarding the MoHE budget format which has been prepared by a committee which included financial managers from public universities in Jordan. This budget format suits public universities as it has been generated from the experience of a public university (Mah'd, 2010).

Respondents from private universities claim that the budget format has been generated to meet MoHE needs. They think that the MoHE force them to follow a budget format that is based on the public university experience. They also declare that this format suites a public institution and Ministry requirements, but that it is not workable in private universities because it ignores the unique situation of commercial targets. Six financial and audit managers support the following view:

"The MoHE budget format comes from a public institution, and it is suitable for public universities, not for commercial ones (I18)."

Another respondent explained that,

"As private, for profit firms, we have commercial accounts that differ from governmental ones or from public universities' accounts. As a financial department, we face several problems in accommodating our accounts to being workable with their budget requirements. We have given this a great deal of effort and time, but it is a waste of time. (I19)." 
The view that universities are unable to use this format efficiently in their operations is supported by about half of the respondents, who think that the MoHE budget format is used for achieving MoHE requirements rather than for decision-making or strategic thinking. They also believe that this format appears to be more for the sake of appearance than for operations.

It also appears that the MoHE has not supplied adequate training courses to private universities. All respondents, including the Ministry staff, agree that the Ministry has not given enough training courses regarding their procedures and rules. An interviewee explained that,

"I think there is no cooperation or development between the MoHE and universities. The MoHE did not give any training courses, seminars or workshops... We cannot understand what their target is, and I think that they themselves do not know exactly what they need. One example of that is the Scientific Research percentage; it is still vague and unclear for all universities. (I13)."

Five respondents in three universities clarify that they have kept their own, parallel, accounts alongside their use of the MoHE requirements. This is because they think that the MoHE requirements cannot fulfill their university's requirements and plans. One interviewee comments that universities' managements know their accounts better than the Ministry does. She summarizes these points by saying:

"Firstly, private universities are different to public universities. Secondly, there is a disconnect between private and public universities and the Ministry, and, finally, unexpected and unexplained changes always occur; therefore, we keep our own accounts and procedures. (I13)."

Jordanian law stipulates that every private university must reserve $5 \%$ of its operational expenses for scientific research. This includes $3 \%$ for seminars, conferences, training courses, publication, and research funding, as well as $2 \%$ as scholarships for PhD students (Mah'd, 2010).

The MoHE claims that they ask private universities to comply with their rules to make sure that the private university separates the accounts related to the parent company from the accounts related to the university, and the Ministry assumes that any accounts related to building maintenance or instructions are company accounts. An interviewee in the financial department in the Ministry explains,

"It is not our job to control these universities or to influence the universities' decisions regarding what and where they should spend; these are internal decisions and every university enjoys its autonomy.... Our task is to ensure that private universities spend 5\% of their operational expenses for the purpose of scientific research, and to separate the educational accounts from the commercial ones. (I9)."

Four financial managers in private universities comment on this problem and highlight some points with which they struggle. One financial manager says:

"There is a big gap between the laws: the HE Law, the Income Tax Law, and the Companies' Law. For instance, according to the Companies' law, we are required to contribute $1 \%$ of our profit to Jordanian universities."

$1 \%$ to scientific research, and $1 \%$ to training. Therefore, they deal with us as private companies. Yet, at the same time, they ask us to work as auniversity, and we do not receive anything from this contribution. Meanwhile, public universities do not pay these percentages but do receive the contribution. Moreover, the HE Law forces us to deduct $5 \%$ of our operational expenses for scientific research, although this conflicts with the Companies' law

The interviewees who are on the MoHE staff think that most private universities collaborate with the MoHE and follow the ministry procedures and rules. The budget coordinator in the MoHE states that:

"All the private universities are cooperative, and they provide us with all necessary information. It is not obligatory for the universities to include an item which is not in their accounts; they can simply ignore this item and, if there is need to add it to the final budget, then add it and tell us. (I5)."

One financial manager in a private university agrees with this, stating:

"Ministry rules are suitable to all private universities, because they are not based on a certain number of faculties or departments. (I17)."

Universities' revenues typically come from student tuition fees, which are committed in advance. Enrolments fluctuate every year and, in consequence, it is not possible for the university management to have an accurate knowledge about the costs of the services they provide or the costs of different student types enrolled. This is very important for university strategies. A financial manager in one university details that:

"The budget is not flexible; it cannot be changed according to our income. The problem is that our 
income depends on student numbers, and we cannot change the expenses according to student numbers during the year. The MoHE asks us to do so."

The results show that most of the respondents think that the MoHE is using the budget to oversee and control the private universities. The respondent also agreed that public universities are not following the direction of the MoHE in many occasions. What is uniques in Jordan that private universities are paying to the MoHE and they are following the roles while public are receiving fund from the government but they are not following the roles.

\section{Conclusion}

The MoHE claims that, while each university in Jordan maintains its autonomy, the MoHE is concerned about the quality of education in these universities. The MoHE thinks that the budget process is one way of protecting educational quality by maintaining an appropriate percentage of scientific research, keeping commercial companies away from the educational process, and gathering budget information to match and compare for the purpose of research and development. More than two thirds of private universities think that the MoHE is trying to oversee private universities and to centralise strategic decisions into the hands of the MoHE through the budget. The following are points which have been highlighted by some of the interviewees.

1) There is conflict between HE laws and other laws. Inconsistencies and contradictions exist between the responsibilities and authorities in both Laws of HE and Companies. For example, in HE Law, the budget must be authorized by the board of trustees, and the president is responsible for making expenditure decisions, while in the Companies' Law this authority is given to the management board (owners). This conflict is one of the main problems facing private universities in Jordan.

2) Private universities are not well represented in the MoHE council (Farhan, 2000). While there are more private universities than public universities, every public university is represented in the MoHE council by its president, while all private universities are represented by just one person. There is dissatisfaction amongst private universities because they are ignored and underrepresented. Some, like the former president of one private university, assert that representation should be based on university or student numbers. Farhan (2000) comments on the way in which the MoHE deals with the universities: - this is unfair and reflects imbalance in dealing with the national universities, since their voice is ignored.

3) The accreditation system is applied to private universities but not to public ones. According to Burke and Al-Waked (1997), there is a conceptual bias that private universities provide lower educational quality than public universities do. The MoHE asks all private universities to implement different criteria regarding quality of education, financing, management, and other issues, while this is not a requirement for public universities. According to Farhan (2000), there is discrimination in dealing with universities and this has a negative impact on the educational process. According to all interviewees in private universities, inequality exists in the MoHE's treatment of private and public universities. Indeed, there is evidence to suggest that some private universities perform much better that some public universities do in terms of educational services, development, and student quality. One question that has been raised to the budget directors in the MoHE is: Why do you ask private universities to implement a budget format while this is not a requirement for public universities?'

To this query, one MoHE representative replied:

"The law states that universities must submit their budgets; we are working on that, and soon public universities will also submit their budget forms and follow the same regulations."

\section{Acknowledgements}

The authors are grateful to Applied Science Private University, Amman, Jordan, for full financial support granted to this research project.

\section{References}

Al-lamki, S. M. (2002). Higher education in the sultanate of Oman: The challenge of access, equity and privatisation. Journal of Higher Education Policy and Management, 24(1), 75-86. http://dx.doi.org/10.1080/13600800220130770

Altbach, P. G., \& Knight, J. (2007). The internationalization of higher education: Motivations and realities. Journal of Studies in International Education, 11(3-4), 290-305. http://dx.doi.org/10.1177/1028315307303542

Buckland, R. (2009). Private and public sector models for strategies in universities. British Journal of Management, 20(4), 524-536. http://dx.doi.org/10.1111/j.1467-8551.2008.00593.x 
Burke, D. L., \& Al-Waked, A. A. (1997). On the threshold: Private universities in Jordan. International Higher Education, 9(Fall).

Covaleski, M. A., \& Dirsmith, M. W. (1988). An institutional perspective on the rise, social transformation, and fall of a university budget category. Administrative Science Quarterly, 33(4), 562-587. http://dx.doi.org/10.2307/2392644

Covaleski, M., Evans, I., John, H., Luft, J., \& Shields, M. D. (2003). Budgeting research: Three theoretical perspectives and criteria for selective integration. Journal of Management Accounting Research, 15(3), 3-49. http://dx.doi.org/10.2308/jmar.2003.15.1.3

Drury, C. (2012). Management and cost accounting. London: Thomson Learning, Business Press.

El-Sheikh, E., Mah'd, O., Nassar, M., \& Khadash, H. (2012). Financing and management of higher education: Evidence from Jordan. International Business Research, 5(5). http://dx.doi.org/10.5539/ibr.v5n5p71

Farhan, E. (2000). Organizing higher education sector in Jordan. Zarka Private University, Higher Education in Jordan, Zarka, WP.

Horngren, C., Foster, G., Datar, S., Rajan, M., \& Ittner, C. (2015). Cost accounting: A managerial emphasis (15th ed). New York, NY: Pearson Higher Education.

Issa, S. S. (2000). Quality assurance of engineering education in private universities in Jordan. International Journal of Higher Education, 6(2), 119-128.

Johnstone, B. (1998). The finance and management of higher education: A status report on worldwide reforms. State University of New York, New York, NY.

Kharman, N. (2005). Educational developments in Jordan: A comparison of private and public schools (Unpublished PhD Thesis). University of Reading, Reading.

Magner, N. R., Rahman, M., \& Welker, R. B. (1996). The interactive effect of outcome favorability and procedural justice in work resource allocation on work performance. Journal of Applied Social Psychology, 26(9), 825-842. http://dx.doi.org/10.1111/j.1559-1816.1996.tb01133.x

Mah'd, O. (2010). The budgetary process in Private Jordanian Universities (PJUs) and the role of budget participation (Unpublished PhD Thesis). School of Accounting and Finance, University of Aberdeen, Aberdeen.

Mah'd, O., \& Buckland, R. (2009). The budget process in Jordanian Private Universities (JPUs). Accounting in Emerging Economies, 9, 193-228. http://dx.doi.org/10.1108/S1479-3563(2009)0000009010

Mah'd, O., Nassar, M., Nimer, K., \& Al-okdeh, S. (2011). The impact of managers' related variables and department features on budget characteristics: The case of private Jordanian Universities. International Business Research, 4(4), 199-210.

Ministry of Education. (2008). Inclusive education: The way of the future. The 48th Session of Education. Geneva.

Ministry of Higher Education. (2001). The temporary law of private universities 43. Ministry of Higher Education, Amman, Jordan.

Ministry of Higher Education. (2009). The law of Jordanian Universities 20. Jordanian Government, Ministry of Higher Education.

Modell, S. (2006). Triangulation between case study and survey methods in management accounting research: An assessment of validity implications. Management Accounting Research, 16(2), 231-254. http://dx.doi.org/10.1016/j.mar.2005.03.001

Moll, J. (2003). Organisational change and accounting control systems at an Australian University: A longitudinal case study (Unpublished PhD Thesis). School of Accounting and Finance, Griffith, Griffith University.

World Bank. (1996). Jordan higher education development study. Amman, Jordan, Human Resources Division, Country Department II, Middle East and North Africa Region: No.15105-Jo.

Younis, A. M. (2002). Standards for library education in private universities in Jordan. International Information and Library Review, 34(4), 369-394. http://dx.doi.org/10.1006/iilr.2002.0216 


\section{Copyrights}

Copyright for this article is retained by the author(s), with first publication rights granted to the journal.

This is an open-access article distributed under the terms and conditions of the Creative Commons Attribution license (http://creativecommons.org/licenses/by/3.0/). 